tieth century, in the modern English-language picture of the world, ethnicity is conceptualized as a cultural construct. Ethnicity becomes a means of accentuating cultural specificity, which is expressed in a twofold increase in the number of exotic words in the OALD dictionary, compared to the ALDCE dictionary, the use of ethno-marked tokens as an attribute to cultural artifacts in the OALD IR dictionary.

The study showed that ethnicity is a dynamic product of the discourse of the era, constructed in different contexts and different types of texts. Taking into account ethnicity in the linguistic description contributes to a fuller understanding of the English-language picture of the world, deepens scientific ideas about the interaction of ideology, language, culture.

Keywords: ethnicity, illustrative context, concept, representations of ethnicity, katoikonymov, ethnochoronyms, politically correct ethnonyms, tokens.

Vitae

Natalia Melnyk is Doctor of Pedagogical Sciences, Associate Professor, Department of Foreign Philology, Faculty of Linguistics and Social Communications National Aviation University (Kyiv).

Correspondence: loroknataliia@gmail.com

Надійшла до редакції 26 лютого 2021 року Рекомендована до друку 12 березня 2021 року

Мар'яна Оленяк

ORCID: orcid.org/0000-0002-5888-326X

Володимир Манакін

DOI 10.31558/1815-3070.2021.41.20

УДК 81 '3

\title{
ІДІОЛЕКТ СТІВЕНА ХОКІНГА НА РІЗНИХ ЕТАПАХ ПРОГРЕСУВАННЯ БІЧНОГО АМІОТРОФІЧНОГО СКЛЕРОЗУ: СТИЛОМЕТРИЧНИЙ АНАЛІЗ
}

3'ясовано особливості авторства текстів Стівена Хокінга, визначено багатство їхнього лексикону, а також охарактеризовано ступінь виливу вимушених зовнішніх і внутрішніх факторів на мовлення Стівена Хокінга. Встановлено, щчо вимушений вплив зовнішніх факторів (використання системи комунікаиії Intel ma SwiftKey) чи внутрішніх факторів (невпинне прогресування бічного аміотрофічного склерозу) на мовлення С. Хокінга не мало негативних наслідків, а технологія Intel ma SwiftKey була досконалим продуктом, проте виказувала вилив на особливості мовлення професора.

Ключові слова: ідіолект, стилометрія, лексикон, авторство.

Постановка наукової проблеми та іїі актуальність. Антропоцентричний вектор розвитку сучасного мовознавства $\epsilon$ беззаперечним. Він втілюється у багатьох роботах, присвячених ідіолекту окремих особистостей та націй загалом. Вагомих результатів у цьому домені досягли (Ажнюк Л. В. 2016, Григор'єв В. П. 1983, Домилівська Л. В. 2011, Єсипенко Н. Г. 2007, Калимон Ю. О. 2014, Кокіна В. В. 2003, Кононенко В. I. 2008, Кульчицький I. М. 2014, Ліхнякевич I. О. 2014, Мазепова О. В. 2007, Науменко А. М. 2003, Павличко О. О. 2010, Тарасова І. А. 2004, Чистяк Д. О. 2016, Юсслер М. 1987) та ін. Не дивлячись на те, що проблема індивідуального стилю є предметом досліджень багатьох праць філологів, вона залишається не повністю вивченою у вітчизняному мовознавстві, частково через те, що дослідники більшою мірою вивчають особливості ідіостилю автора переважно у художній літературі, що зумовлює і виправдовує існуючі підходи до аналізу ідіолекту: лінгвістичний, лінгвокогнітивний, лінгвокультурологічний, лінгвопоетичний, кількісний та якісний. 
Однак, одним з напрямків прикладного застосування знань про ідіолект є проведення лінгвістичних експертиз, необхідність яких може бути зумовлена різноманітними факторами.

Аналіз досліджень. Проведення лінгвістичної експертизи текстів є відносно новим видом лінгвістичних досліджень, особливо у вітчизняному мовознавстві. Якщо західноєвропейські та американські вчені вже мають напрацьовану методологійну базу, яка постійно вдосконалюється, то у випадку українського мовознавства сьогодні можна говорити лише про великі перспективи розвитку цієї сфери лінгвістики, хоча не можна констатувати повну її відсутність завдяки таким мовознавцям як (Ажнюк Л. В. 2016, Калимон Ю. О. 2014, Кульчицький I. М. 2014, Ліхнякевич I. О. 2014).

Серед провідних закордонних лінгвістичних експертів варто зазначити спеціалістів у сфері фонетики (Hollien H. 1990, 1995; Rose P. 2001) та стилістики (Coulthard R. 1993, 2007; Eagleson R. 1994; Tiersma P. 2002; Woolls D. 2003). Саме такі два головних розділи традиційно виокремлюються західними мовознавцями у домені лінгвістичної експертизи.

Актуальність цього дослідження зумовлена перш за все його новизною, відсутністю подібних розвідок на теренах вітчизняного мовознавства і беззаперечною перспективністю міждисциплінарних наукових напрацювань.

Матеріалом дослідження стали уривки 3 двох наукових робіт відомого британського фізика Стівена Хокінга, написаних у різні періоди прогресування його хвороби: на початку 1966 р. - уривок з першої дисертації, і кілька десятків років після поставленого діагнозу (1996 р.) - передмова до монографії A Brief History of Time.

Мета цієї статті полягає у визначенні можливого впливу штучного інтелекту (синтезатора мовлення, розробленого компанією Intel) та поставленого діагнозу, бічний аміотрофічний склероз, на особливості писемного мовлення професора Хокінга.

Досягнення мети передбачає розв'язання таких завдань: з'ясувати особливості авторства аналізованих текстів; визначити багатство лексикону досліджуваних уривків; охарактеризувати ступінь впливу вимушених зовнішніх і внутрішніх факторів на мовлення Стівена Хокінга;

Об'сктом дослідження виступають лексичні та синтаксичні особливості уривків наукових праць британського фізика, написаних з розривом у кілька десятків років.

Предметом дослідження є стилометричні особливості ідіолекту автора на початку та в кінці його хвороби.

У процесі здійснення дослідження було використано низку методів. Для статистичного аналізу, спрямованого на визначення особливостей авторства аналізованих текстів використовувався метод КУСУМ; для з'ясування характеристик багатства лексикону був використаний метод підрахунків за формулою; тлумачення результатів відбувалося за допомогою описового методу.

Новизна дослідження полягає в тому, що роботи Стівена Хокінга вперше піддаються аналізу з позицій лінгвістичної експертизи на предмет можливого мовленнєвого сліду від неминучого втручання зовнішніх (синтезатор мовлення) та внутрішніх (хвороба) чинників на ідіолект професора.

Виклад основного матеріалу. На різних етапах розвитку мовознавства термін ідіолект вживався паралельно з іншими синонімічними поняттями, такими як «стиль», «стиль автора», «ідіостиль», «індивідуальний стиль», «авторський стиль», «авторський ідіолект». Усі вони використовувалися для позначення характеристик індивідуального мовлення людини, як правило, автора художнього твору, і не мали загальнопогодженого визначення та чітких критеріїв розмежування. Однак, останні кілька десятків років спостерігається тенденція до вживання саме терміну ідіолект для позначення своєрідної манери мовлення особистості. Так, Григор'єв В. П. стверджує, що термін ідіолект вже вкорінився в мовознавстві і має більшменш стале поняття (Григорьев 1983: 4); Науменко А. М. порівнює ідіолект з функціональним стилем, трактуючи перший як нижчий рівень мовленнєвої системи, порівняно з другим, називаючи його стилем конкретного індивіда (Науменко 2003: 203); Юсслер М. інтерпретує 
ідіолект як своєрідну особливу форму мовлення індивіда (Юсслер 1987: 186). У даній роботі термін ідіолект використовується у розумінні Т. Левандовського, який визначає його як манеру мовлення окремого носія мови в певний період, а також сукупність соціальних, територіальних, професійних і психо-фізіологічних мовних особливостей індивіда, які проступають на фонетичному, лексичному і лексико-стилістичному рівнях (Lewandowski 1994: 26).

Лінгвісти підходять до проблеми авторства з позиції того, що кожен носій мови володіє своєю самостійною і індивідуальною версією мовлення, якою він говорить і пише, тобто, власним ідіолектом. Такий підхід передбачає, що цей ідіолект проявляється через індивідуальний та своєрідний вибір мовних одиниць і структур в усному мовленні і на письмі. Кожна людина має великий словниковий запас, накопичений протягом багатьох років, який неминуче відрізняється від вокабуляру інших носіїв мови, і ці відмінності будуть проявлятися не з точки зору наявності реальних доступних елементів, які $є$ спільними для усіх носіїв мови, а через надання особистої переваги під час вибору конкретних мовних одиниць і структур. Серед багатьох стилометричних методів, які постійно вдосконалюються і поповнюються, вартими особливої уваги $є$ ті, які використовуються лінгвістами-експертами, в тому числі під час судових слухань. До таких належать метод КУСУМ і метод обчислення багатства лексикону, які будуть застосовані для визначення стилометричних особливостей мовлення С. Хокінга.

Особистість Стівена Хокінга є загальновідомою. Цей британський фізик $є$ всесвітньо знаним завдяки своїм роботам про простір і час. У 22 роки Стівен захворів на аміотрофічний бічний склероз, який також називають моторним неврозом. Це дегенеративне захворювання призводить до загибелі нейтронів у мозку людини. Така патологія викликає погіршення стану м'язів, що призводить до труднощів при ковтанні, спілкуванні i, в кінцевому підсумку, диханні. Хокінгу прогнозували 2 роки життя, але він прожив понад півстоліття. С. Хокінг використовував синтезатор мовлення, розроблений компанією Intel (технологія SwiftKey). Робота цього пристрою передбачала використання інфрачервоного сенсору, встановленого на його окулярах, який вводив інформацію до його комп'ютера, активуючись за допомогою найменших скорочень м'язів у щоці. Програмне забезпечення переміщувало курсор по рядках і стовпцях букв, тому С. Хокінг міг вибрати необхідну літеру, працюючи щокою. Обрані окремі букви потім утворювали слова і речення. Програмне забезпечення часто оновлювалося, щоб допомогти йому впоратися 3 поступовою втратою контролю над м'язами. 3 метою економії часу і зусиль професора Хокінга, технологія SwiftKey була інтегрована в його систему життєдіяльності таким чином, що вона могла точно передбачити не просто символи (букви), а цілі слова, які він міг би вжити у певному контексті.

Саме той факт, що комунікаційна система Intel та SwiftKey приймала активну участь у формулюванні висловлювань професора Хокінга, маючи можливість самостійно застосовувати свої пропозиції та автокорекції, став мотивацією для проведення даного дослідження 3 метою визначення ступеню втручання штучного інтелекту в авторський стиль відомого фізика.

Встановлення особливостей авторства тексту, як правило, починається з визначення кількості авторів, тобто ступеню самостійності написання тексту. В даному дослідженні авторство С. Хокінга в жодному разі не піддається сумніву, а аналізується на предмет можливого впливу з боку комунікаційної системи Intel та SwiftKey. Гіпотезою дослідження є наявність змін у стилометричних показниках аналізу текстів С. Хокінга на різних етапах його життєдіяльності, викликаних необхідністю використання штучного інтелекту у процесі матеріалізації думок в мовленні.

3 метою визначення можливої інтерференції штучного інтелекту у процес формування текстів професора Хокінга доцільно побудувати графіки КУСУМ, на основі обчислень відхилень від середнього арифметичного довжини речень і слів, що складаються з 2-3 букв, на матеріалі уривків двох наукових праць, написаних С. Хокінгом на початку захворювання і в період значного прогресування хвороби. 
Аналіз за допомогою метода КУСУМ можна продемонструвати на уривку з першої дисертації, написаної С. Хокінгом на ранньому етапі прогресування хвороби у 1966 році, коли професор міг самостійно конструювати речення, не використовуючи синтезатор мовлення:

The idea that the universe is expanding is of recent origin. All the early cosmologies were essentially stationery and even Einstein whose theory of relativity is the basis for almost all modern developments in cosmology, found is natural to suggest a static model of the universe. However, there is a very grave difficulty associated with a static model such as Einstein's which is supposed to have existed for an infinite time. For, if the stars had been radiating energy at their present rates for an infinite time, they would have needed an infinite supply of energy. Further, the flux of radiation now would be infinite. Alternatively, if they had only a limited supply of energy, the whole universe would by now have reached thermal equilibration which is certainly not the case. This difficulty was notices by Olbers who however was not able to suggest any solution. The discovery of the recession of the nebulae by Hubble led to the abandonment of static models in favour of ones which were expanding.

Для демонстрації метода взято лише перший абзац, хоча повний аналіз включає весь вступ до дисертації. За рекомендацією Мортона і Мікельсона (Morton, Michaelson 1978), лінгвістів, які вперше використали цей метод для експертизи тексту, параметрами аналізу було обрано середню довжину речення і середню частотність використання слів з 2-3 букв. Оскільки метод КУСУМ демонструє відхилення від норми, а нормою вважається середнє арифметичне обраного параметра, першим етапом реалізації методу стало визначення середньої довжини речення та середньої кількості слів, що складаються з 2-3 букв, у реченні. В аналізованому повному уривку дисертації показник першого дорівнює 21, а показник другого - 7. Отже, в середньому, довжина речень у вступі складається з 21-го слова, а кількість слів з 2-3 букв у реченні в середньому дорівнює 7. У Таблиці 2.1 подано дані обчислення КУСУМ, які були отримані таким чином: від середнього показника довжини речення (21 слово) віднімаємо показник довжини першого речення (11 слів) і отримуємо показник КУСУМ для першого речення: 21-11=10. Далі, від 21 віднімаємо довжину другого речення (35 слів) і отриману різницю (- 14) додаємо до отриманого показника КУСУМ першого речення: 10-14=-4. Далі, від 21 віднімаємо довжину третього речення (26 слів) і отриману різницю (- 5) додаємо до отриманого показника КУСУМ другого речення: $-4-5=-9$. У такий спосіб продовжуємо обчислювати КУСУМ для усього вступу.

Аналогічним чином обчислюємо КУСУМ відхилень у кількості слів, що складаються з 2-3 букв. Середня кількість таких лексем в уривку дорівнює 7, отже для визначення КУСУМ відхилення у першому реченні, від 7 віднімаємо 5, і різницю (2) записуємо у КУСУМ відхилення від середньої кількості слів. Так продовжуємо до кінця уривку. Отримані таким чином дані зображені у Таблиці 2.1.

Табличя 2.1

Кількісні показники КУСУМ в уривку першої дисертації С. Хокінга

\begin{tabular}{|c|c|c|c|c|}
\hline $\begin{array}{c}\text { № } \\
\text { речення }\end{array}$ & $\begin{array}{c}\text { Кількість } \\
\text { слів у ре- } \\
\text { ченні }\end{array}$ & $\begin{array}{c}\text { КУСУМ відхилення } \\
\text { від середньої кіль- } \\
\text { кості слів у реченні }\end{array}$ & $\begin{array}{c}\text { Кількість слів, що } \\
\text { складаються 3 2-3 } \\
\text { букв у реченні }\end{array}$ & $\begin{array}{c}\text { КУСУМ відхилення } \\
\text { від середньої кіль- } \\
\text { кості слів 3 2-3 букв }\end{array}$ \\
\hline 1 & 11 & 10 & 5 & 2 \\
\hline 2 & 35 & -4 & 13 & -4 \\
\hline 3 & 26 & -9 & 6 & -3 \\
\hline 4 & 26 & -14 & 9 & -5 \\
\hline 5 & 10 & -3 & 4 & -2 \\
\hline 6 & 25 & -7 & 9 & -4 \\
\hline 7 & 15 & -1 & 7 & -4 \\
\hline 8 & 24 & -4 & 12 & -9 \\
\hline
\end{tabular}


За даними, отриманими у Таблиці 2.1 , складаємо діаграму з двох ламаних, які відображають показники КУСУМ для обох параметрів (рис. 2.1).

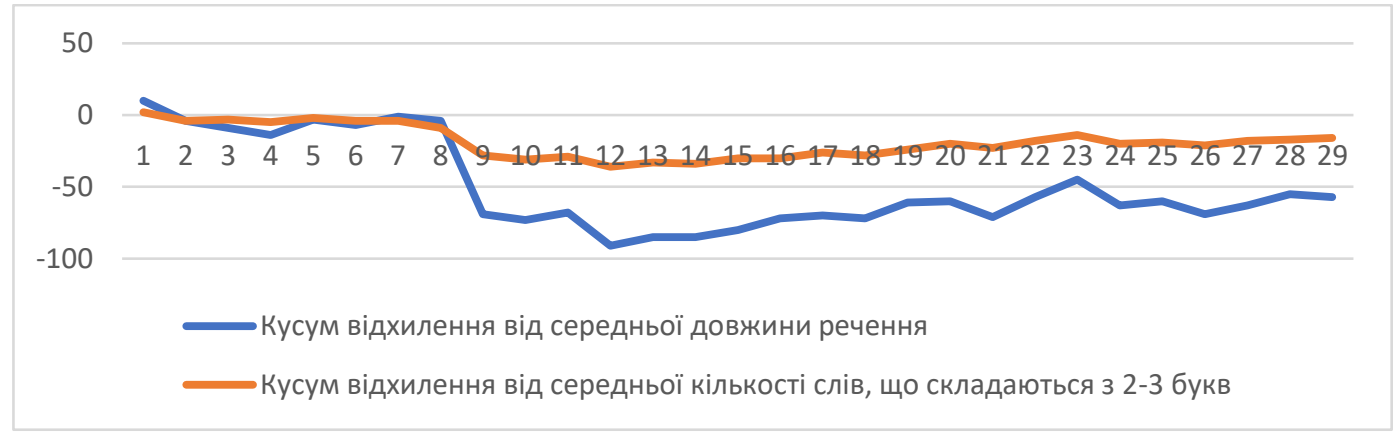

Рис. 2.1 Показники КУСУМ в уривку першої дисертації С. Хокінга

Горизонтально, рисунок показує кількість речень в аналізованому уривку (технічні обмеження редактора Word дозволяють відобразити лише 29 із 38-ми). Вертикальна інтерпретація діаграми дозволяє побачити наскільки дві ламані «відтіняють» одна одну. Як стверджують Мортон і Мікельсон (Morton, Michaelson 1978), якщо ламані діаграми відтіняють одна одну, то текст належить одному автору; якщо вони розходяться у різні напрямки, то $\epsilon$ висока ймовірність втручання сторонньої особи у написання тексту. На рис.2.1 очевидним $\epsilon$ те, що напрямок розгортання двох ламаних співпадає, і вони відтіняють одна одну по всій довжині. Цей факт свідчить про те, що втручання у написання тексту сторонніх осіб відсутнє, і авторство аналізованого уривку першої дисертації належить виключно Стівену Хокінгу.

Здійснивши аналогічним чином аналіз уривку монографії С. Хокінга A Brief History of Time, передмову до якої він написав у 1996 році, через 30 років після поставленого діагнозу, будучи залежним від синтезатора мовлення, отримаємо Рисунок 2.2

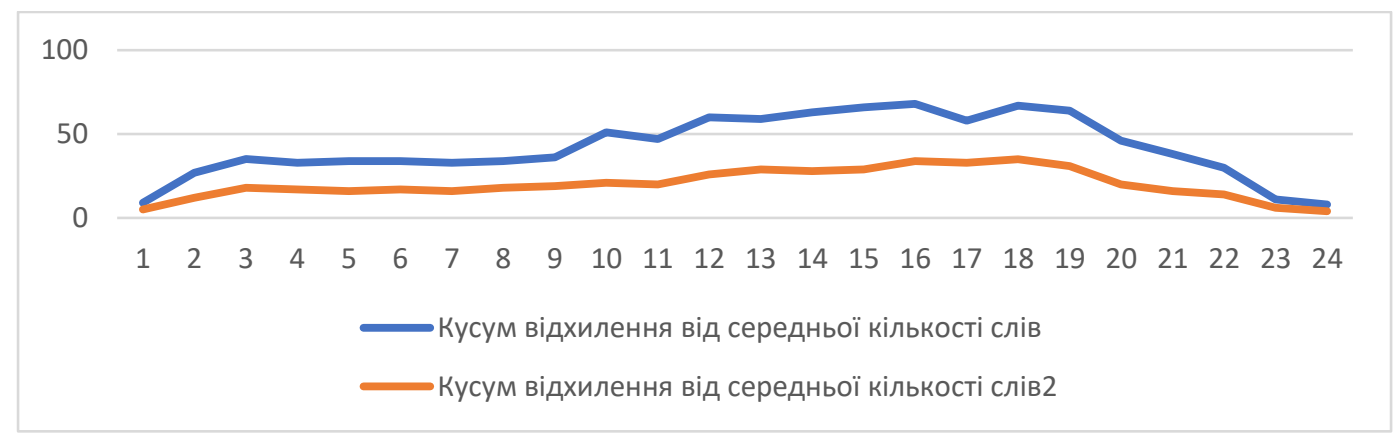

Рис. 2.2 Показники КУСУМ в передмові до монографії С. Хокінга A Brief History of Time

Не зважаючи на те, що середня довжина речень у другій монографії С. Хокінга збільшилася (тут вона складає 24 слова), як видно з діаграми, ламані, по всій своїй довжині, відтіняють одна одну, що говорить про відсутність зовнішнього втручання в написання тексту С. Хокінгом. Таким чином, гіпотеза про те, що необхідність використання синтезатора мовлення призведе до змін мовленнєвих звичок професора, на даному етапі дослідження не підтверджується. Це свідчить про дуже високу якість комунікаційної системи Intel тa SwiftKey, яка досконало вивчила мовленнєві звички С. Хокінга і, будучи індивідуально орієнтованою технологією, не впливала на характер його мовлення.

Стилометричні методи дають змогу «вимірювати» стиль автора, подаючи точні статистичні результати аналізу. Використання програмного забезпечення AntConc суттєво полегшує процес підрахунків і мінімізує можливість похибок.

3 метою визначення можливого впливу системи комунікації Intel та SwiftKey на мовлення С. Хокінга, яка пропонувала професору цілі слова, або й навіть і готові фрази, необхідно використати метод визначення багатства лексикону. Для цього доцільно скористатися формулою Вуллса

$$
100 \times \log \mathrm{N} /(1-\mathrm{LV} 1 / \mathrm{V})
$$


де $\mathrm{N}$ - загальна довжина тексту, кількість слів (знаків),

LV1 - сума повнозначних слів-hapax legomena,

$\mathrm{V}$ - загальна кількість лексики з точки зору типів лексем, яка дозволяє зіставляти тексти, різні за розміром.

Скориставшись програмою для лінгвостатистичного аналізу AntConc, отримуємо такі статистичні дані:

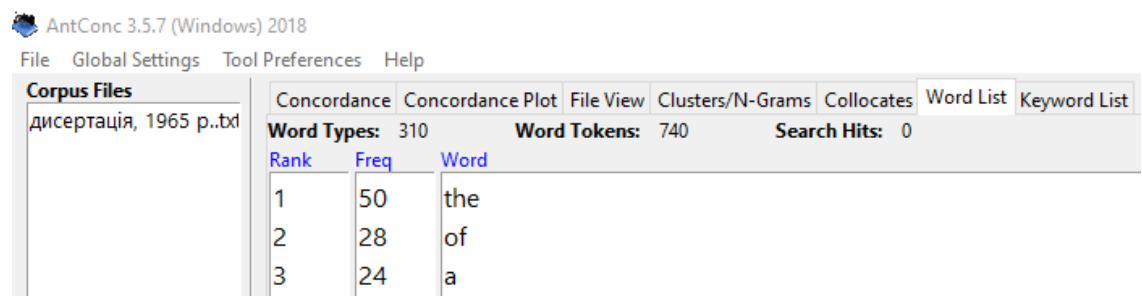

Рис. 2.5 Загальні статистичні дані (кількість слів та кількість типів лексем) першої дисертації С. Хокінга

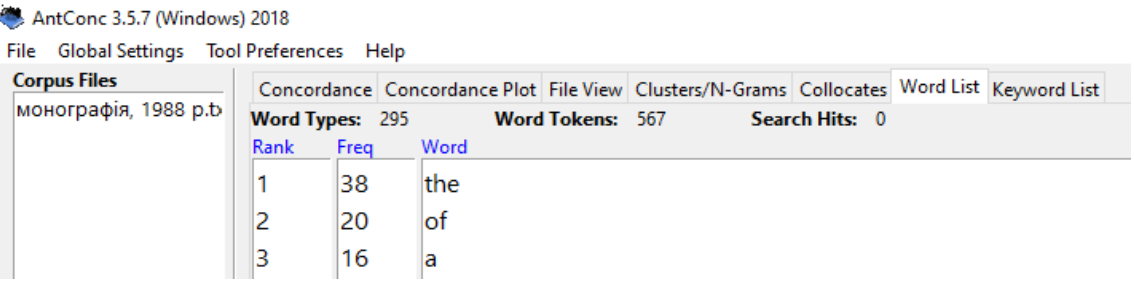

Рис. 2.6 Загальні статистичні дані (кількість слів та кількість типів лексем) монографії С. Хокінга

Узагальнені кількісні дані з двох досліджуваних уривків, необхідні для обчислення багатства лексикону С. Хокінга, подані у Таблиці 2.2.

Таблиия 2.2

Статистичні дані аналізованих уривків дисертацій С. Хокінга, необхідні для обчислення багатства лексикону.

\begin{tabular}{|l|c|c|}
\hline \multicolumn{1}{|c|}{ Елемент формули } & $\begin{array}{c}\text { Кількість у першій } \\
\text { дисертації }\end{array}$ & $\begin{array}{c}\text { Кількість у } \\
\text { монографії }\end{array}$ \\
\hline $\mathbf{N}$ - загальна довжина тексту, кількість слів (word tokens) & 740 & 567 \\
\hline $\mathbf{L V 1}$ - сума повнозначних слів-hарах legomena & 194 & 220 \\
\hline $\begin{array}{l}\text { V- загальна кількість лексики з точки зору типів лексем } \\
\text { (word tyреs) }\end{array}$ & 310 & 295 \\
\hline Багатство лексикону & $\mathbf{7 8 6}$ & $\mathbf{1 0 8 3}$ \\
\hline
\end{tabular}

Вертикальне прочитання таблиці показує кількісні характеристики кожного з аналізованих текстів, горизонтальна інтерпретація таблиці дає змогу зіставити характерні особливості писемного мовлення С. Хокінга на різних етапах прогресування хвороби. Як бачимо з таблиці, багатство лексикону професора Хокінга значно збільшилося з часом. Можна припустити, що досвідченість і професіоналізм, які з роками зростали, $є$ причетними до підвищення показників багатства лексикону професора, проте роль синтезатора мовлення не варто недооцінювати в цьому аспекті. Система, по-суті, видавала тезаурус, повний перелік релевантних, потенційно необхідних професору у даному контексті, слів чи фраз, з яких Стівен Хокінг вибирав конкретний відповідник. На ранньому етапі своєї наукової діяльності, коли відомий фізик ще міг говорити і писати самостійно, у нього не було можливості здійснити вибір тієї чи іншої лексеми 3 готового переліку, «банку» релевантних лексем, що може слугувати причиною наявності меншої концентрації hapax legomena в тексті першої дисертації. Як правило, формулюючи свої думки, людина може витрачати досить багато часу на пошук «влучного» слова, 
і не завжди успішно. Іноді доводиться змиритися з тією лексемою, яка спала на думку, не вважаючи їі достатньо влучною, тільки тому, що іншу не вдається підібрати. Людині завжди легше віднайти «влучне» слово чи уникнути лексичних повторів, якщо є можливість скористатися словником синонімів, тому вимушене втручання системи комунікації Intel та SwiftKey можна вважати чинником, який суттєво і позитивно вплинув на збагачення лексикону професора Хокінга. Отже, на цьому етапі дослідження, гіпотеза про можливий вплив комунікаційної системи на мовлення С. Хокінга повністю підтвердилася.

Висновки. Авторство аналізованих уривків наукових праць Стівена Хокінга не викликає сумніву. Результати підрахунків, проведених за допомогою використання метода КУСУМ, свідчать про одноосібність авторства досліджуваних текстів.

Вимірювання багатства лексикону на різних етапах прогресування хвороби показало позитивну динаміку. Різниця між написанням двох праць складає понад тридцять років, i, як показують результати дослідження, багатство лексикону у текстах С. Хокінга різко зросло: від 786 (багатство лексикону в тексті, який формулювався самостійно, без допомоги технологіï Intel та SwiftKey) до 1083 (багатство лексикону в тексті, який формулювався не самостійно, а $з$ допомогою технології Intel та SwiftKey).

Результати проведеного дослідження дозволяють стверджувати, що вимушений вплив зовнішніх факторів (використання системи комунікації Intel тa SwiftKey) чи внутрішніх факторів (невпинне прогресування бічного аміотрофічного склерозу) на мовлення С. Хокінга не мало жодних негативних наслідків: середня довжина речень з роками зростала, як і багатство використовуваного вокабуляру. Можна впевнено говорити, що технологія Intel тa SwiftKey була досконалим продуктом, розробленим для професора. Вона настільки ідеально «навчилася» відтворювати мовленнєві звички автора, що залишається непомітною під час обчислення КУСУМ, відхилень від середньостатистичної норми. Проте, зростання багатства лексикону Стівена Хокінга майже у 1,4 рази в період використання системи комунікації Intel та SwiftKey під час формулювання думок свідчить про наявність впливу штучного інтелекту на особливості мовлення професора. Однак, вплив цей швидше $є$ позитивним, ніж негативним.

Перспектива цієї розвідки полягає в тому, що методи, використані в ній, можуть у подальшому бути застосованими під час аналізу особливостей авторства інших текстів. Результати аналізу можуть бути використані для (анти)реклами синтезатора мовлення, вони також можуть бути корисними для тих, хто працює з пацієнтами, що страждають від бічного аміотрофічного склерозу.

\section{Література}

Ажнюк, Леся. «Типологія об’єктів лінгвістичної експертизи і методика їх дослідження». Мовознавство 3, 2016: 3-18.

[Azhnyuk, Lesya. «Typolohiya ob"yektiv linhvistychnoyi ekspertyzy i metodyka yikh doslidzhennya». Movoznavstvo 3, 2016: 3-18.]

Григорьев, Виктор П. Грамматика идиостиля: бібліографічний опис. Москва: Наука, 1983.

[Grigor'yev, Viktor P. Grammatika idiostilya: bibliografichniy opis. Moskva: Nauka, 1983.]

Домилівська, Людмила В. Ідіостиль Юрія Яновського в контексті лінгвоестетичних парадигм I половини XX ст.: автореф. дис. ... канд. філол. наук : 10.02. Київ, 2011.

[Domylivs'ka, Lyudmyla V. Idiostyl' Yuriya Yanovs'koho v konteksti linhvoestetychnykh paradyhm I polovyny KhKh st.: avtoref. dys. ... kand. filol. nauk : 10.02. Kyyiv, 2011.]

Єсипенко, Надія Г. Лексико-семантичні компоненти авторського стилю і мовна картина світу (на матеріалі англомовної прози воєнної та мирної тематик): автореф. дис. ... канд. філол. наук: спец. 10.02.04. Чернівці, 2007.

[Yesypenko, Nadiya H. Leksyko-semantychni komponenty avtors'koho stylyu i movna kartyna svitu (na materiali anhlomovnoyi prozy voyennoyi ta myrnoyi tematyk): avtoref. dys. ... kand. filol. nauk: spets. 10.02.04. Chernivtsi, 2007.] 
Калимон, Ю., Кульчицький, І., Ліхнякевич, І. «Ідіолект, ідіостиль, індивідуальний стиль. Тотожне чи різне?». Науковий вісник Східноєвропейського наџіонального університету імені Лесі Українки 5, 2014: 226-229.

[Kalymon, Yu., Kul'chyts'kyy, I., Likhnyakevych, I. «Idiolekt, idiostyl', indyvidual'nyy styl'. Totozhne chy rizne?». Naukovyy visnyk Skhidnoyevropeys 'koho natsional'noho universytetu imeni Lesi Ukrayinky 5, 2014: 226-229.]

Кокіна, Вікторія В. «Статистичний аналіз дієслівної лексики в авторському стилі». Мова $i$ культура 6, 2003: 63-69.

[Kokina, Viktoriya V. «Statystychnyy analiz diyeslivnoyi leksyky v avtors'komu styli». Mova $i$ kul'tura 6, 2003: 63-69.]

Кононенко, Віталій. Мова у контексті культури: бібліографічний опис. Івано-Франківськ: Плай, 2008.

[Kononenko, Vitaliy. Mova u konteksti kul'tury: bibliohrafichnyy opys. Ivano-Frankivs'k: Play, 2008.]

Мазепова, Олена В. Лінгвістичні особливості ідіостилю Сохраба Сепехрі: : автореф. дис. ... канд. філол. наук : 10.02.13. Київ, 2007.

[Mazepova, Olena V. Linhvistychni osoblyvosti idiostylyu Sokhraba Sepekhri: : avtoref. dys. ... kand. filol. nauk : 10.02.13. Kyyiv, 2007.]

Науменко, Анатолій М. Блуканина сучасного перекладу: від глухого кута семіотики до глухого кута когнітивної лінгвістики. Запоріжжя: ЗДУ, 2003.

[Naumenko, Anatoliy M. Blukanyna suchasnoho perekladu: vid hlukhoho kuta semiotyky do hlukhoho kuta kohnityvnoyi linhvistyky. Zaporizhzhya: ZDU, 2003.]

Павличко, Оксана О. «Щодо статистичних параметрів авторського стилю (на матеріалі творів Е. М.Ремарка)». Мовні і концептуальні картини світу 29, 2010: 186-191.

[Pavlychko, Oksana O. «Shchodo statystychnykh parametriv avtors'koho stylyu (na materiali tvoriv E. M.Remarka)». Movni i kontseptual'ni kartyny svitu 29, 2010: 186-191.]

Тарасова, Ирина А. Поэтический идиостиль в когнитивном аспекте (на материалі поезіі Г. Иванова и И. Аненского): : дис. ... доктора филол. наук: 10.02.01. Саратов, 2004.

[Tarasova, Irina A. Poeticheskiy idiostil' v kognitivnom aspekte (na materiali poyezii G. Ivanova i I. Anenskogo): : dis. ... doktora filol. nauk: 10.02.01. Saratov, 2004.]

Чистяк, Дмитро О. «Дослідження художнього концепту в лінгвопоетичній перспективі». Науковий вісник ДДПУ імені І. Франка. Серія «Філологічні науки. Мовознавство 5, 2016: 157159.

[Chystyak, Dmytro O. «Doslidzhennya khudozhn'oho kontseptu v linhvopoetychniy perspektyvi». Naukovyy visnyk DDPU imeni I. Franka. Seriya «Filolohichni nauky. Movoznavstvo 5, 2016 : 157-159.]

Юсслер М. Социолингвистика бібліографічний опис. Київ: Вища школа, 1987.

[Yussler M. Sotsiolingvistika bibliografichniy opis. Kiïv: Vishcha shkola, 1987.]

Coulthard, Malcolm R. 'Beginning the study of forensic texts: corpus, concordance, collocation', in M P Hoey (ed.), Data Description Discourse, London: HarperCollins. 1993: 86-97.

Coulthard, M. R., Johnson A. An introduction to forensic linguistics: language in evidence. London: Routledge. 2007.

Eagleson, Robert. «Forensic analysis of personal written text: a case study», in J Gibbons (ed.) Language and the Law, London, Longman. 1994: 362-373.

Hollien, Harry. The Acoustics of Crime, New York: Plenum. 1990.

Hollien, Harry. «Consideration of guidelines for earwitness lineups». FL 3, 1995: 14-23

Lewandowski T. Linguistisches Wörterbuch. Heidelberg; Wiesbaden: Quelle Meyer, 1994.

Morton, A., Michaelson, S. The qsum plot. University of Edinburgh, Department of Computer Science. 1990.

Morton, Andrew Q. Literary Detection: How to Prove Authorship and Fraud in Literature and Documents. Epping, Essex: Bowker. 1978. 
Rose P., Clermont, F. «A comparison of two acoustic methods for forensic discrimination». Acoustics Australia 29/1, 2001: 31-5.

Tiersma P., Solan L. «The linguist on the witness stand: forensic linguistics in American courts». Language 78, 2002: 221-39.

Woolls, David. «Better Tools for the Trade and how to Use them». Forensic Linguistics. The International Journal of Speech, Language and Law, 2003: 102-112.

\section{Використані джерела}

Hawking, Stephen. A Brief History of Time <https://royallib.com/book/Hawking_Stephen/a _brief_history_of_time.html> 24.12.2020.

Hawking, Stephen. Properties of expanding universes https://cudl.lib.cam.ac.uk/view/MS-PHD05437/1 24.12.2020.

\section{THE IDIOLECT OF STEPHEN HAWKING AT DIFFERENT STAGES OF AMYOTROPHIC SCLEROSIS PROGRESSION: STYLOMETRIC ANALYSIS Mariana Oleniak, Vladimir Manakin \\ Theory and practice of translation department, Germanic philology department; Vasyl Stus Donetsk National University; Vinnytsia; Ukraine.}

\section{Abstract}

Background: The relevance of this investigation is accounted for the lack of such kind of research in the domain of national linguistics and the prospect of interdisciplinary studies.

Purpose: The purpose of the work is to determine the possible impact of the artificial intelligence and the diagnosis on the features of Professor Hawking's written language.

Results and discussion: The following tasks have been solved in the course of the study: the results of linguistic research devoted to idiolect have been generalized and systematized; the peculiarities of the authorship of the analysed texts have been determined; the vocabulary richness of the studied extracts has been calculated; the degree of influence of involuntary external and internal factors on the speech of Stephen Hawking has been characterized.

It has been determined that the involuntary influence of external factors (using the Intel and SwiftKey communication system) or internal factors (continuous progression of lateral amyotrophic sclerosis) on S. Hawking's speech had no negative effects, and Intel and SwiftKey technology was a perfect product for the purpose. However, Stephen Hawking's increase in the vocabulary richness by nearly 1.4 times during the use of the Intel and SwiftKey communication systems while expressing his thoughts indicates the presence of artificial intelligence in the professor's speech features.

Key words: idiolect, stylometry, vocabulary, authorship.

Vitae

Mariana Oleniak, $\mathrm{PhD}$, associate professor Theory and practice of translation department of Vasyl Stus Donetsk National University; interested in historical linguistics and forensic linguistics.

Correspondence: m.oleniak@donnu.edu.ua.

Vladimir Manakin, Doctor of Philology, professor of Germanic philology department of Vasyl Stus Donetsk National University; interested in general linguistics and linguocultural studies.

Correspondence: v.manakin@donnu.edu.ua. 